\title{
IMMUNOHISTOCHEMICAL DETECTION OF CALCITONIN IN PARAFOLLICULAR CELLS OF THE THYROID GLAND OF THE LABORATORY RAT (Rattus norvegicus var. alba Linné, 1758)
}

\author{
H. CERNÝ. E. ČERNÁ' \\ Department of Anatomy, Histology and Embryology, 'Department of Pathological Physiology, University of \\ Veterinary and Pharmaceutical Sciences Brno
}

Received May 14. 1998

Accepted Auguist 19, 1998

\begin{abstract}
Černý H., E. Černá: Immunohistochemical Detection of Calcitonin in Parafollicular Cells of the Thyroid Gland of the Laboratory Rat (Rattus norvegicus var. alba Linné, 1758). Acta vet. Brno. 1998. 67: 139-143.

The aim of the present work was to test the efficiency of the set used for the detection of calcitonin in the rat and describe its tissue topography on the basis of parafollicular cell (PC) visualization. MILAB-ICC Immunohistochemistry Set was used for the immunohistochemical detection of calcitonin. For the final full-colour visualization. PAP complex binding was used. The results were recorded by photomicroscopy with differential interference contrast mode (Nomarski), and they revealed that PCs occurred in thyroid interfollicular regions as independent cells or in the form of cellular clusters. In their position between follicles. PCs leaned against the basal membrane of follicular cells (FCs). In the narrow parafollicular regions, they touched basal membranes of several follicles and were situated between several FCs.

The immunopositive and immunonegative results indicate the stages of functional activity and dormancy of PCs. respectively. Using this principle. the light microscopy showed well-defined areas of local activity and functional reserves among PCs.
\end{abstract}

\section{Calcitonin, MILAB-ICC Immunohistochemistry Set, histotopography, parafollicular cells}

Until quite recently, it was generally assumed that parafollicular cells of the thyroid gland, which belong among branchiogenic organs, are formed from the entodermal layer of the ventral projection of the 4th and 5th entobranchial clefts as an ultimobranchial body. The cellular material of the body is integrated in the thyroid gland base even before the gland descends.

Cells of the original ultimobranchial body disperse in the thyroid base and populate the region between differentiating follicles.

In his embryology textbook, Schnorr (1985) presented the theory that parafollicular cells developed from the cells of the neural crest and, as mobile cells, migrated to the area of the primitive pharynx, where they formed the ultimobranchial body.

The neural crest origin of parafollicular cells has received significant support from a number of recent works. Differentiated endocrine cells secrete not only calcitonin but also serotonin (Tamir et al. 1994).

Data from recently published works on the role of parafollicular cells suggest that the cells are not only responsible for the secretion of calcitonin (hence their name C-cells), but also of other regulatory peptides usually called paracrine or autocrine factors. For that reason, they found their place among the cells of the so-called APUD system (Sawicki 1995). 
Using the immunocytochemical detection method. Sawicki and Zabel (1997) compared parafollicular cells of the thyroid gland with the remnants of the ultimobranchial bodies in the European bison. They found immunopositive cells not only in parafollicular regions of the thyroid gland, but also in the structures of the persisting remnants of ultimobranchial bodies where parafollicular cells formed groups of net-shaped cellular formations. A number of those cells were immunohistochemically negative and their cytoplasmic organelle apparatus characterised them as immature. Histomorphological analysis showed that the immunohistochemical or immunocytochemical detection could be used to study the heterogeneity of parafollicular cell populations in persisting ultimobranchial bodies.

The aim of the present study was to investigate the tissue topography of parafollicular cells (the so-called C-cells) and, based on their visualisation, to define their current functional activity. In the methodological part of the project, the authors also wanted to test the suitability of a human set for the calcitonin detection in animal species.

\section{Materials and Methods}

Thyroid glands of eight adult laboratory rats (both sexes) were prepared in toto. Tissue samples were fixed in Bouin's fluid and 10\% solution of neutral formol. After dehydration in an ascending alcohol series, tissue blocks were set in paraplast and cut in 5-7 $\mu \mathrm{m}$ sections.

For the immunohistochemical detection. the authors used a method similar to that used in the detection of endocrine G-cells in the mucous membrane of the stomach (Černy et al. 1991). The only difference was the use of the commercially available MILAB - ICC Immunohistochemistry Set for the detection of calcitonin in tissue sections. For the final full-colour visualization. the PAP complex binding was used.

Results were recorded by microphotography using the differential interference contrast technique with the socalled Nomarski effect.

\section{Results}

Immunohistochemical visualization of parafollicular cells showed that those cells were present in the thyroid gland of the rat in both forms described to date, i.e. both as single cells and in cellular clusters.

The cells are always located in parafollicular regions between individual follicles, and their relationship with follicular cells is expressed by the fact that some of the parafollicular cells lean against their basal membrane from the other side. In the narrow space between follicles, they find themselves in the bilateral interposition between basal membranes of neighbouring follicles.

From the histotopographical point of view, the distribution of parafollicular cells is irregular (see Plate I., Figs 1 and 2, Plate II.. Fig. 3). Immunohistochemical reaction of the cells to calcitonin is immunopositive in some cases and immunonegative in others. Regional immunopositive and immunonegative reactions define the pattern of the current functional status of parafollicular cells in the organ studied.

Under high magnifications. and particularly when the differential interference contrast is used, the centrally localised large light nucleus and immunopositively responding cytoplasm are prominent, the latter containing secretory vesicles with calcitonin that are visualised as dark-brown secretion product. A careful examination of individual cells reveals the perinuclear localisation of a marked immunopositive reaction to calcitonin which, in relation to cellular poles. is often arranged asymmetrically. The authors believe that this finding is most probably related to the perinuclear localisation of the Golgi's complex. 
Parafollicular cells with centrally sectioned nucleus exhibit more pronounced immunopositive reaction than cells sectioned tangentially, i.e. their immunopositive reaction is disproportionally weaker.

\section{Discussion}

The efforts at re-definition and more accurate determination of the origin of parafollicular cells of the thyroid gland in the last decade have also influenced the theories of their role. Particularly important in this respect was the revision of until recently the only accepted theory according to which parafollicular cells developed from the entoderm. The entirely new hypothesis that is gaining ground today identifies the ectoderm as the layer where these cells develop. They reach the thyroid base via the ultimobranchial bodies ( Ta mir et al. 1992).

Cytological characteristic of parafollicular cells (PC) and their histotopographical relationship to follicular cells (FC) of the thyroid gland help us to explain and better understand their roles.

Under the light microscope, PCs appear as light cells with weakly-staining cytoplasm containing isolated cisterns of the endoplasmic reticulum, well-defined structure of the Golgi's complex, numerous mitochondria and a large number of minute secretory vesicles (Nunez and Gershon 1978; Delman and Brown 1987). The organelle apparatus suggests secretory activity of the PCs. A comparison of immunochemical reactions showed a correlation between the reaction product and the cytoplasmic organelle apparatus. It explains the often perinuclearly situated immunopositive reaction as a result of the Golgi's complex localization. Tiny calcitonin-containing cytoplasmic granules in the surrounding cytoplasm give a positive reaction.

PCs in the thyroid gland are found either as isolated cells or as cellular clusters. In the dog, Delman and Brown (1987) reported a prevalence of cellular clusters over solitary PCs. Our findings suggest that both types of cellular formations can be found between the follicles of the rat.

Recent papers have indicated an increasing interest in the PCs and particularly in their role. New studies have demonstrated that PCs are not only responsible for calcitonin secretion, but that they also secrete other metabolically active substances. Tanimura et al. (1989) proved that in addition to calcitonin, PCs also secrete somatostatin, which is attributed with local regulatory effects on the secretion of calcitonin. TSH and parathormone, because similar somatostatin-competent cells were also found in parathyroids.

A hren's study (1991) enriched our knowledge by showing that in addition to calcitonin and somatostatin. PCs also accumulate calcitonin-gene-related peptide, gastrin-releasing peptide, catalcalcin and heterodermin. Their function affects the secretion of TSH and thus they influence the control of the activity of FCs in the thyroid gland.

The close functional relationship between PCs and FCs in the thyroid gland was reported by T a m ir et al. (1992). In addition to substances mentioned earlier, PCs also accumulate the neurotransmitter 5-hydroxytryptamin (5-HT). through which they can immediately influence the FC activity. In view of a close topographical relationship of the two types of thyroidal cells (they are only separated by the basal membrane). Ta mir et al. (1992) proposed a theory that 5-HT played a role in the intercellular signalling, with FCs being the target cells. At the same time, they proved that the secretion of 5-HT alone evokes TSH in the presence of extracellular calcium. For that reason any change in the extracellular calcium concentration, on the other hand, was able to affect cytoplasmic calcium concentration and calcitonin secretion. 
From narrowly conceived and specialised research of PCs, new original histophysiological conclusions were drawn that gave us a substantially better and more detailed insight into the $\mathrm{PC}$ function.

Fig. 1-3 show a light microscopy image where local functional activity and the PCs ${ }^{*}$ part in the activity is demonstrated through immunopositive reaction. From the image we can also assume that PCs in another region are immunonegative, i.e. functionally inactive, and serve as a functional reserve of the thyroid gland's PCs.

The authors also confirmed the suitability of the commercially available set for immunohistochemical demonstration of calcitonin in the rat.

\section{Imunohistochemický průkaz kalcitoninu v parafolikulárních buňkách štítné žlázy potkana (Rattus norvegicus var. alba Linné, 1758)}

Cílem naší práce bylo ověřit účinnost použitého setu pro průkaz kalcitoninu u vybraného animálního druhu a na základě vizualizace parafolikulárních buněk (PB) určit jejich tkáňovou topografi. $\mathrm{K}$ imunohistochemickému průkazu jsme použili soupravu fy MILAB - ICC Immunohistochemistry pro průkaz kalcitoninu. Konečné barevné vizualizace bylo dosaženo vazbou PAP komplexu. Výsledky jsme dokumentovali na fotomikroskopu za použití diferenciálního interferenčního kontrastu (Nomarski).

PB se vyskytovaly $v$ prostorech mezi folikuly thyroidey jako samostatné buňky nebo v podobě buněčných shluků.

V interpozici mezi folikuly naléhaly na basální membránu folikulárních buněk (FB). V úzkých parafolikulárních prostorech se dotýkají basálních membrán dvou nebo více folikulů.

Imunopozitivita prokazuje funkční aktivitu, naopak imunonegativita je důkazem klidové fáze PB. Na tomto základě je v obrazu světelného mikroskopu zřejmá lokální aktivita a funkční rezerva mezi jednotlivými $\mathrm{PB}$.

Ověřili jsme účinnost MILAB-ICC setu pro průkaz kalcitoninu u vybraného animálního druhu.

\section{References}

AHREN. B. 1991: Regulatory peptides in the thyroid gland- a review on their localization and function. Acta Endocrinol. 124: 225-232

AMBROSIUS, H., LUPPA, H. 1987: Immunohistochemie. Grundlagen und Techniken. Akadem. Verlag Berlin, $229 \mathrm{p}$.

ČERNY. H.. MAZÁNEK, S.. CERNÁ. E. 1991: Immunohistochemical localization of endocrine G-cells in the epithelium of the pars pylorica mucosa of the cat and mouse stomach. Acta Vet. Brno 60: 317-322

DELMAN. D. H., BROWN. M. E. 1987: Texbook of Veterinary Histology, 3.ed. Lea and Febiger, Philadelphia, $468 \mathrm{p}$.

KAMEDA. Y., SHIGEMOTO. H., IKEDA 1980: Development and cytodifferentiation of C cell complexes in dog fetal thyroids. An immunohistochemical study using anti-calcitonin. antiC-thyroglobulin and anti-19S thyroglobulin antisera. Cell Tiss. Res. 3: 403-415

LARSON. L. I., GOLTERMANN, N.. De MAGISTRIS, L., REHFELD, J. F., SCHWARTZ. T. W. 1979: Somatostatin cell processes as pathway for paracrine secretion. Science 205: 1393-1394

NICKEL, R., SCHUMMER, A. . SEIFERLE. E. 1975: Lehrbuch der Anatomie der Haustiere. Band IV. Verlag Paul Parey, Berlin und Hamburg, $426 \mathrm{p}$

NODEN, D. M., de LAHUNTA. A. 1985: The Embryology of Domestic Animals. Developmental Mechanisms and Malformations. Williams and Wilkins. Baltimore-London-Los Angeles-Sydney, $367 \mathrm{p}$.

NUNEZ, E. A., GERSHON, M. D. 1978: Cytophy'siology of thyroid parafollicular cells. Int. Rev. Cytol. 55: 1-6

RUSSO, A. F., CLARK, M. S.. DURHAM. P. L. 1996: Thyroid parafollicular cells. An accessible model for the study of serotonergic neurons. Mol. Neurobiol. 13: 257-276

SAWICKI. B. 1995: Evaluation of the role of mammalian thyroid parafollicular cells. Acta Histochem. 97: 389-399 
SAWICKI, B., ZABEL, M. 1997: Immunohistochemical study of parafollicular cells of the thyroid and ultimobranchial remnants of the European bison. Acta Histochem. 99: 223-230

SCHNORR, B. 1985: Embryologie der Haustiere. Ferdinand Enke Verlag, Stuttgart, 244 p.

STERNBERGER, L. A. 1966: Immunocytochemistry (3rd ed). Wiley, New York, 523 p.

TAMIR, H., HSIUNG, S. C.,YU, P. Y., LIU, K. P., ADLERSBERG, M., NUNEZ, E. A., GERSHON, M. D. 1992: Serotonergic signalling between thyroid cells: $\mathrm{C}$ and 5-HT2 receptors in the secretion and action of serotonin. Synapse 12: $155-168$

TAMIR, H. PISCOPO, I.,LIU, K. P., HSIUNG, S. C., ADLERSBERG, M., NICOLAIDES, M.. al AWQATI, Q., NUNEY, E. A., GERSHON, M. D. 1994: Secretagogue-induced gating of chloride channels in the secretory vesicles of parafollicular cells. Endocrinology 135: 2045-2057

TANIMURA, N. TATEYAMA, S.,YAMAGUCHI, R., NOSAKA, D. 1989: Immunohistochemical demonstration of somatostatin-containing cells in the equine thyroid und parathyroid glands. Jap. J. Vet. Sci. 51: 228-230 
Plate I.

Černý H., Černá E.: Immunohistochemical... pp. 139-143.

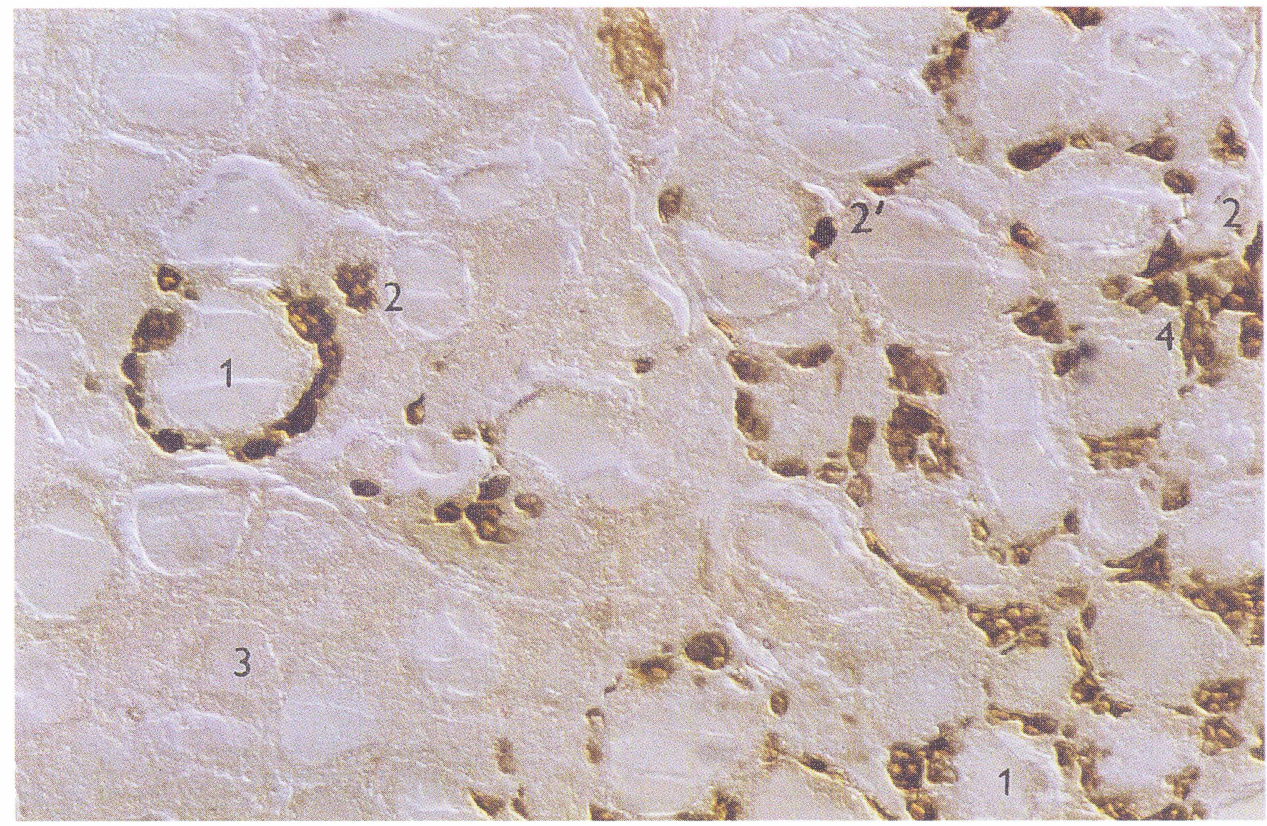

Fig. 1 (× 40). For legend see Plate II.

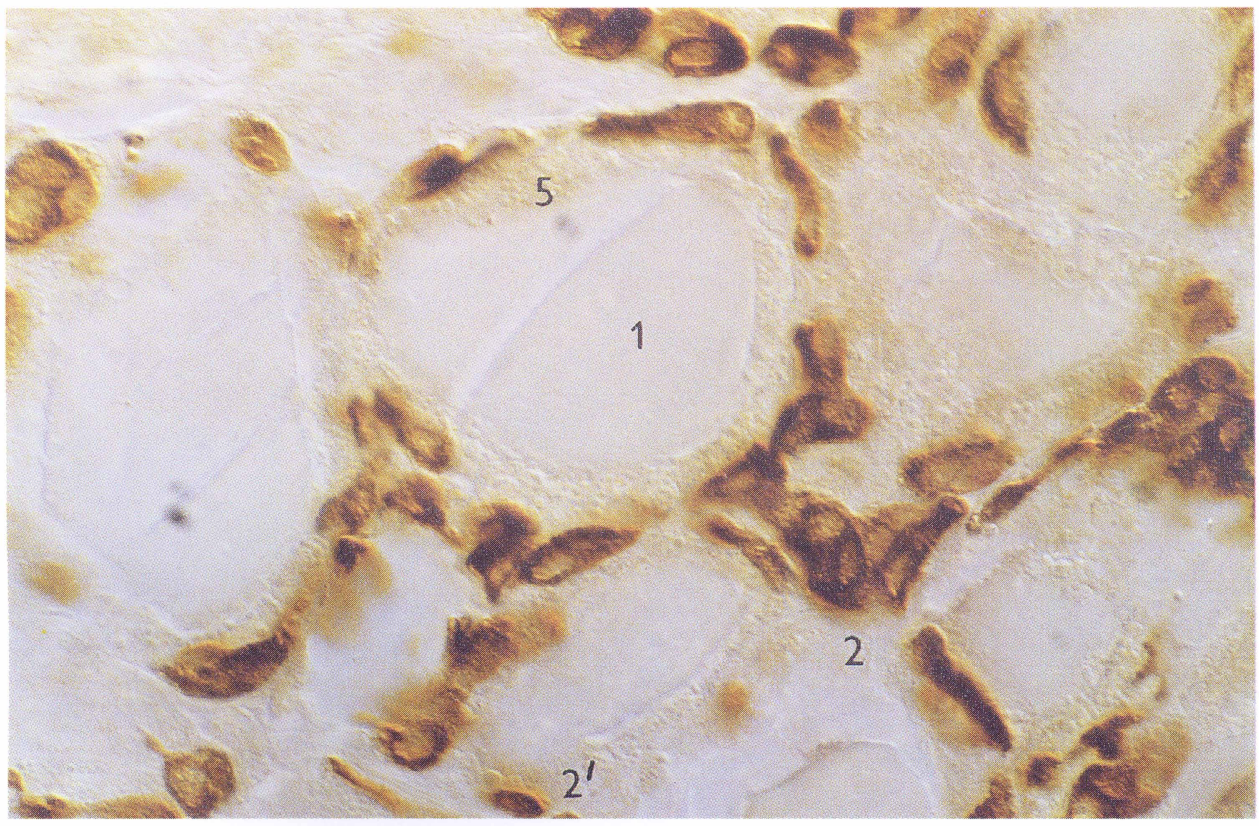

Fig. $2(\times 200)$. For legend see Plate II. 


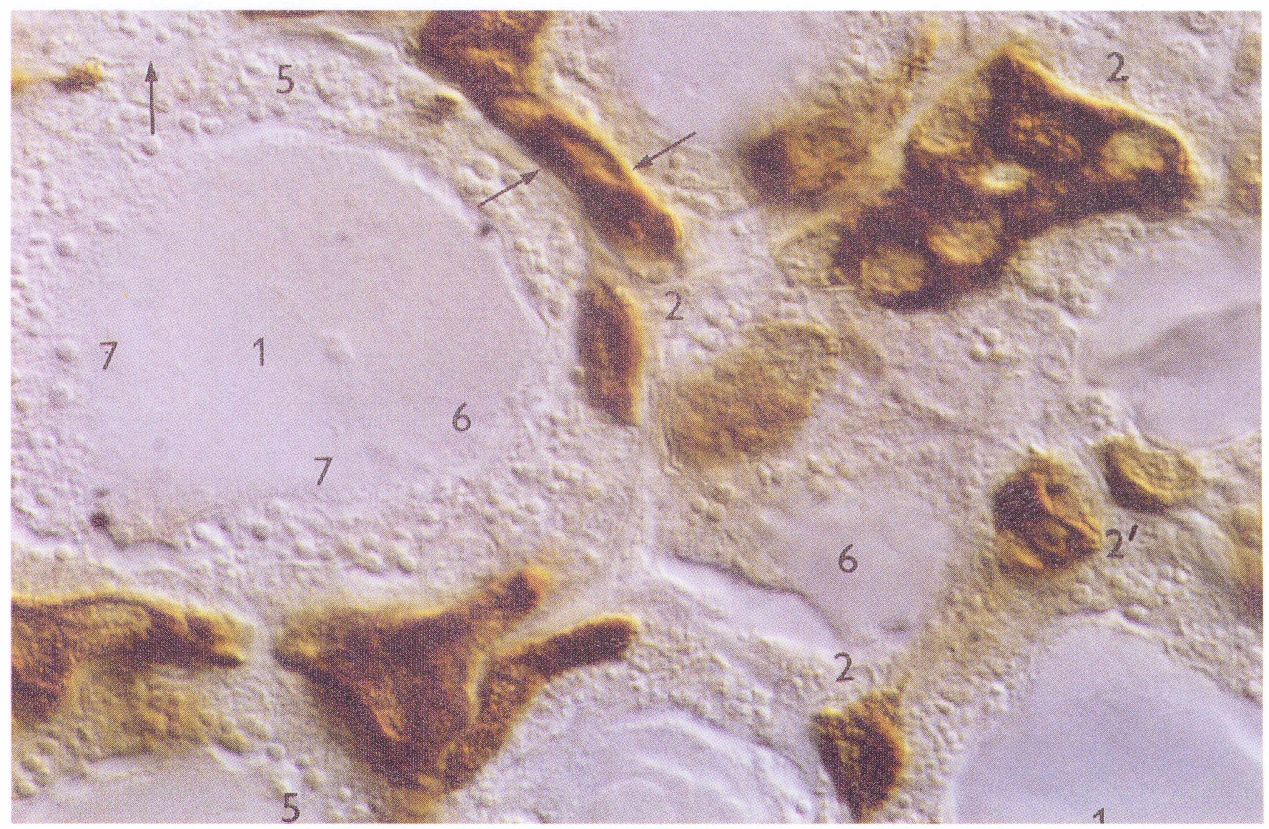

Fig. $3(\times 400)$.

Immunohistochemical detection of calcitonin in PCs of the rat thyroid gland under different magnifications: 1-follicular cavity filled with colloid, 2-individual parafollicular cells and their clusters with a positive reaction to calcitonin, 3-thyroid tissue in the dormant stage which is expressed as immunonegative reaction of PCs, 4-marked PC immunopositive reaction in the topographically active region of the thyroid gland, 5-follicular cells (FCs), 6-colloid in the follicle cavity, 7-secretory vesicles are particularly well-defined in Fig. 3, when Nomarski effect was used, arrows in Fig. 3 show the basal membrane between follicular and parafollicular cells and delineate the parafollicular region. 